\title{
SOURCES OF FINANCING PUBLIC PASSENGER TRANSPORT SERVICES
}

The paper deals with the financing of public passenger transport. It analyses unconventional types of financing public passenger transport abroad. The aim of the paper is to present the methodology of creating funding sources for the financing of public passenger transport which is applicable in the Slovak Republic and in the member states of the European Union. The key idea of the methodology is to use funding sources arising from the provision of public services.

Keywords: Transport, passenger transport, financing, source, acquisition, transport service.

\section{Introduction}

Public passenger transport is one of many important elements of the socio - economic environment in which the public passenger transport operates. Public passenger transport is characterised as a public service. Its main task is to satisfy transport requirements, e.g. transport to work, school, hospital, offices, etc. To a great extent, the service is provided by bus service and railway transport of the Slovak Republic. Suburban bus service, regional rail services and city transport play an important role in the transport services of conurbations.

It is necessary to spend considerable funds for right and quality operation of public passenger transport. The state has an obligation to provide transport services in its whole territory even if the services are not cost - effective.

Providers use their own public budgets to cover the financial losses. In the USA, financing from public sources covers from 57 to $89 \%$ of operating costs in bus service while in railway transport it covers from 29 to $89 \%$ of operating costs [1]. In the EU, financing from public budgets covers from 23 to $50 \%$ of operating costs [2 and 3], depending on the system of financing in the particular state of the EU. In general, it is not possible to finance public passenger transport only from transport revenues and advertising revenues. This statement is supported by studies that were elaborated before
1990, e.g. Bly et al. [2] or Pucher and Markstedt [4]. The situation in the Slovak Republic is the same as in other European countries. The public passenger transport is funded from public budgets but these sources are not sufficient. The aim of this paper is to identify unconventional ways of the financing of transport services.

\section{The current way of financing transport services}

The financing of public services in public passenger transport is covered by the Regulation (EC) No 1370/2007 on public passenger transport services by rail and by road, which defines the method whereby a contracting authority provides public services in public passenger transport. The aim of this Regulation is to achieve a greater number of services, the increase of road safety and the quality of provided services with the lowest possible costs. The Regulation specifies conditions which have to be respected by contracting authorities when ordering transport services which are funded from public sources. The amount paid from public sources cannot exceed the net financial impact, which is the sum of positive or negative impacts of compliance with obligations resulting from public services on expenses or revenues of a public services provider.

\footnotetext{
* ${ }^{1}$ Milos Poliak, ${ }^{1}$ Lenka Komackova, ${ }^{2}$ Salvador Hernandez, ${ }^{3}$ Marek Jaskiewicz, ${ }^{4}$ Gabriela Boldizsarova

${ }^{1}$ Department of Road and Urban Transport, Faculty of Operation and Economics of Transport and Communications, University of Zilina, Slovakia ${ }^{2}$ School of Civil and Construction Engineering, Oregon State University, Corvallis, Oregon, USA

${ }^{3}$ Department of Automotive Vehicles and Transportation, Faculty of Mechatronics and Machine Engineering, Kielce University of Technology, Poland ${ }^{4}$ The Institute of Lifelong Learning, University of Zilina, Slovakia

E-mail: lenka.komackova@fpedas.uniza.sk
} 


\subsection{The Slovak Republic}

The funding of transport services is divided among three contracting authorities in the Slovak Republic. Municipalities are contracting authorities for transport services in the area of the town which are funded from the town budget. Regional bus service is provided by autonomous regional administration which does not have any appropriations committed to this purpose but it finances transport services directly from the regional budget. The rail transport service is provided by the state administration - the Ministry of Transport, Construction and Regional development of the Slovak Republic which finances transport services from its resources in the state budget. The Slovak Republic has no model which would define any fees or taxes as a source of transport service funding.

\subsection{Belgium}

In Belgium, the federal state is responsible for rail transport. Regional governments are responsible for other public transports such as bus service, tramways and underground. The state finances rail transport. In the case of an increased interest of regional governments in some investment projects in rail transport they may co-finance these projects. Other types of public transport are financed by regional and local governments.

The main source of funding for both the state and autonomies are tax revenues. Resources in rail transport come from the tax revenue from the state budget. Public transport in towns is a part of regional transport [5].

\subsection{The Czech Republic}

In 2005, the rationalisation of responsibility for public services was finished in the Czech Republic. Since 2005, the public services have been provided by three levels of contracting authorities:

- Regions or providers of public services authorised by regions are responsible for providing transport services in their territorial districts. They order regional public rail services, i.e. Sp trains and OS trains (regional express and passenger trains), and municipal bus services.

- Towns may order lines of city transport.

- The Ministry of Transport orders national trains, i.e. R trains, Ex trains and EC trains (fast train, Express and EuroCity) to provide connection between main conurbations of the Czech Republic.

Transport services in the Czech Republic are also provided by commercial services. Coach transport, international bus transport and long distance rail transport are mostly operated on commercial basis.

Regions are given committed subsidies for providing public transport services by rail transport. The Ministry of Transport provides transport services in passenger transport by public rail transport on the basis of the contract of public services with Ceske drahy, a. s. (JSC) The transport services funding is mainly obtained from the state budget which is formed of general tax revenues. The public resources bound to public transport are divided according to the percentage among the contracting authorities - The Ministry of Transport, autonomous regions and towns [6].

\subsection{Denmark}

The rail transport in Denmark is funded from the Danish government budget and from the fare revenues. The bus service is funded in a similar way. It is not funded by the state but by local autonomous regions and from the fare revenues. In general, the contribution of the state subsidies in transport covers one half of the costs and the other half is covered by the passenger revenues. City transport consists mainly of bus service which is funded by respective cities. Resources for public transport services funding are obtained from tax revenues [5].

\subsection{Estonia}

Rail transport in Estonia, both regional and long distance, is funded by the state which also funds suburban bus service to a great extent. About $70 \%$ of costs in rail transport are covered from public funding. In regional bus service it is about $60 \%$ of total costs which are funded by the state. City transport including tramways and trolleybuses is funded by towns. Long distance bus service and all international services are operated on the commercial basis, which means they are funded by the fare revenues. The sources of financing which are not covered by the fare revenues are obtained from the general tax revenues. The operation of city transport is funded by cities. The state can contribute to funding in the case of significant investment projects like the renovation of tramways or the modernisation of the fleet in Tallinn [5].

\subsection{Ireland}

In Ireland, the National Transport Authority subsidises public passenger transport. The state funds everyday bus and rail operation which cannot be procured on commercial basis. 
Resources for public bus service operation and rail transport operation mainly consist of the fare revenues and the state subsidies [5].

\subsection{Iceland}

The bus service in Iceland is divided into two parts: urban and suburban. The bus system in Reykjavik is financially supported by state subsidies because of the underdeveloped infrastructure for cars resulting from the Icelandic transport plan. The amount covers about a quarter of the total costs. Another quarter of the costs is covered by the passenger revenues and the remaining part is formed by the finances from local governments (town budgets and adjacent urban regions) [5].

In suburban regions, the bus system is partially funded by state subsidies. The other part comes from the local autonomous regions. As in most countries, the state subsidies are obtained from tax revenues, however, in Iceland they are obtained directly from driving fuel taxes.

Iceland has no rail transport because there is no railway infrastructure. As a result, the population in Iceland very often uses domestic flights in a similar way as most people in the European Union use railway lines for distances over 350 kilometres. Domestic flights to some distant areas are subsidised according to the selection procedure.

\subsection{Lithuania}

In Lithuania, there are two ways of providing resources for public passenger transport. The first is funds from the whole state budget or local autonomous regions. The second way are the structural funds of the European Union.

The state and the structural funds of the European Union support the public railway transport. The bus transport is funded by local autonomous regions and the structural funds of the European Union [5].

\subsection{Austria}

According to the act on local and regional public passenger transport, two public authorities are responsible for managing and financing of public transport:

- Federal bureau is responsible for basic services in local and regional public railway transport;

- Regional or local administrative bodies are responsible for planning of demand-oriented services.

That is the reason why railway transport lies within the area of responsibility of the federal government and provincial governments unlike the bus transport which is provided by provincial governments and towns.

Federal bureaus obtain resources for public passenger transport financing from the federal budget which is formed by tax fees. Provinces and towns finance public passenger transport from their budgets to the extent possible. There are also contracts between provinces and federal autonomous regions which are aimed at the co-financing of agreed services with the federal government (e.g. special tariffs for students, total free fare for pupils and students). At the municipal level, there are some taxes and fees in order to fund public transport, e. g. in Vienna, the local administrative body increased taxes for companies to fund the operation of the underground.

In Austria, city transport is financed from city budgets and from the resources of the Transport Association of which cities must be a member. Subsequently, in compliance with territorial and price levels they receive grants [5].

\subsection{Switzerland}

In Switzerland, resources for the financing of transport services are from different sources. The most important incomes are: mineral oils tax ( $50 \%$ of the tax is for transport), excess tax from motor fuels, and non-specific subsidies the origin of which is not specified. Resources are offered to different institutions, e.g. to the Public Passenger Transport Fund or the Infrastructure Fund, which then allocate the resources for a particular purpose (public passenger transport expenses, significant railway projects, etc.). City transport is mostly financed from city budgets [5].

\section{Unconventional ways of financing of transport services}

Based on the analysis of conditions in the selected states, it is possible to say that it is necessary to finance public passenger transport from other sources than the revenues from transport. Mostly, the transport services are funded from public budgets but in many states, the funding of public passenger transport is costly. Apart from traditional sources of financing it is possible to consider unconventional ways of funding. In the case of these sources a certain share of taxes or fees is bound to the transport services funding. In the following part, there are identified ways of unconventional transport services financing. 


\subsection{Employee tax and employer tax}

Employer taxes and local income taxes are usually collected by national and local governments around the world but there are some cities in which the taxes are closely linked to payments to the public passenger transport systems. In the United States and Europe, local payroll taxes are used for public passenger transport (e. g. in the United States in Portland and Eugene, Oregon). Oregon permitted local transport authorities to use payroll taxes for generating the revenue. Louisville and Cincinnati use local income taxes to subsidise public passenger transport.

In Europe, employer taxes as a source of financing for transport service are applied in France. The first tax collecting was in Paris in 1971 and later it extended to smaller provincial towns [7]. The tax has to be paid by companies with more than nine employees unless they live in a company precinct or companies provide them with their own transport. A similar way of financing is used with the underground in Vienna [8].

\subsection{Taxes linked to property}

A part of the nature of property tax lies in the concept of providing public passenger transport which brings an advantage to property users (in this case the increase of the property value) [9]. This mechanism is defined as a mechanism which makes authorities responsible for the development of the city transport infrastructure and allows them to obtain a part of financial benefits from land developers or society. This advantage is reflected in the rise of the real property value which can be considered as a complex index of all advantages formed by development, including better availability and the increase of business opportunities. This "recuperation of value" process is divided into taxes and single or irregular developer fees. The tax can be defined as a regular property payment and continuous amounts to a local or regional government which later allocates subsidies for public passenger transport. Paying for providing public services by the property (or the land) is a common practice in the world and can be observed in the whole of Europe, Asia and North America. However, in most cases, the resources are collected by authorities and then allocated to each sector according to the actual political purposes. In North America, nevertheless, the allocation of property taxes to fund public transport is common in cities like Minneapolis, New York, Denver, Detroit, Miami, Los Angeles, San Francisco and Vancouver [10 - 11]. Examples of the allocation of property taxes outside North America are rare but can be found in Japan (Osaka), India (Mumbai) and Spain (Barcelona).

\subsection{Development fees}

The reaching of the value is not necessarily limited to property taxes because the development fees can be implemented. Sims and Berry [12] state that the collected value from specific taxes and charges comprises:

- Development fees - a part of transport costs would be reclaimed by special fees for various uses of the land usually charged in the time of a new development of the property in lucrative areas.

- Advantages sharing is bound to the property value increase resulting from public investments.

- Density bonusing, near public transport stations whereby the participation in a programme is voluntary. Developers can choose if they participate or not. They will get some extra "density" or extra permissions to build but they have to pay for them. A similar kind of scheme is tendering or auction of "density" where a fixed value of density is put into the auction.

- Connection fee, whereby the owner of the property pays a specific fee for a direct connection with a transport system.

Examples of implementation in real life of these kinds of schemes are known around the world. Many of them can be found in North America, e. g. San Francisco, Washington and Portland. In Europe, development fees are used in Hamburg, Germany. Common development programmes began in Hong Kong and Japan [8].

\subsection{Parking charges and fines}

Parking charges are a common part of our life and they are used by local authorities to finance their activities [13 and 14]. Charges in general cannot be perceived as an unconventional mechanism. However, these charges are rarely hypothecated to support public passenger transport or as a part of a planned transport financing package. There are clear examples in England. In Milton Keynes, revenues of parking charges are dedicated to support public passenger transport which is a part of transport and parking strategy. The example points at the potential of these charges linked to environmental and transport planning processes. There is another program implemented at the Heathrow, Stansted and Gatwick airports where passengers contribute an average $€ 0.31$ from every parking transaction to support public passenger transport. In Amsterdam, revenues from central city parking are used for partial financing of a new traction line. Similar implementations can be found in the world, e. g. Aspen (Colorado), Miami (Florida), La Spezia, Verona and Milan in Italy [8]. 


\subsection{Fees for using road space}

The idea of collecting fees for using roads is one of the oldest. Already at the end of 17 th century and at the beginning of 18th centuries, many of roads in the U.S.A. were built as private toll roads. Recently, a toll road has become interesting again, especially in the European Union. One of more traditional reasons is to generate revenue for the construction of new roads. The second and newer reason is to correct traffic congestion and air pollution but the revenues can also be used to support public passenger transport. Although charging of roads (and congestions) is not widely implemented, there is some experience where revenues are transferred to finance public passenger transport.

The city roads toll in Europe is a phenomenon of Scandinavian countries [7]. The toll in Bergen (first time used in 1986), Oslo (1990) and Trondheim is a "cordon system". The vehicles (public transport vehicles are free) pay for the entrance to the centre of city and revenues are used for the financing of road investments and public passenger transport investments. The toll is also common in the United States but it is often linked to the use of bridges and tunnels. Some of the toll revenues can be hypothecated to public passenger transport. In San Francisco, Golden Gate Bridge tolls are used for supporting inter-county transport services including buses and ferries. In New York and Philadelphia, bridge toll and tunnel toll are important financial sources as well. These examples were aimed at the increase of revenues but there are implemented programmes aimed at the reducing of congestions. Congestion fees have been collected in Singapore since 1975 (Small and Gómez-Ibáñez, 1998). Some of the fees from Area License Scheme (ALS - congestion toll in Singapore) are to improve public transport as a substitute for car transport. A similar scheme is used on the highway (international I-15) near San Diego. In this scheme, users can choose the congestion lanes or to pay for the congestion free lanes. This kind of fee depends on the level of congestion on the highway. The revenues are partly used to finance express bus services in the corridor I-15 [8].

\subsection{Local motoring taxes}

A local motoring tax is a tax collected from drivers by local jurisdiction for local purposes (one of them is public passenger transport). It is collected in addition to the state and federal fuel tax. Motor vehicle taxing is common all over the world (taxes are usually collected nationally) but the revenues are rarely directly allocated (on a local basis) to finance specific objectives. Local motoring taxes may have different forms and they are relatively common in the United States, mainly fuel tax and excise tax.
There are two types of local fuel taxes in Florida - a gas tax approved by voters and a fuel tax approved by the authorities. A local motor vehicle excise tax has been implemented in Washington. It is an annual excise tax on the fair market value of the vehicle. Towns and districts may direct half of the tax revenues for public passenger transport needs. In St. Clara (California), the fuel tax is used to finance the local contribution to the light railway in San Jose [11].

Other examples out the United States are not very known although there are some programmes implemented in Canada as well (e. g. Vancouver, Montreal). In Lisbon (Portugal), public transport is financed from the fees on diesel oil. Since 1967 there has been taxation in Germany allocating 0.026 from one litre of the sold fuel for investments in city roads and public transport [8].

\subsection{Consumption tax}

In general, the consumption tax is a tax imposed on consumer goods such as general goods, specific services and luxury items and energies (e.g. gas). The consumption taxes may bring dedicated finance resources to transport authorities and through their implementation the authorities may collect revenues for operating and capital costs. Transport agencies often use taxes to compensate for the decreasing state grants, to build significant investment projects or to supplement operating revenue. This kind of taxes is common in the United States.

The consumption tax in the most states in the U.S.A. has the value of $0.5 \%$ from the value of the goods but it represents a great part of the operation of public passenger transport funding. In some towns, the tax is applicable to any sold goods and the collected tax is used to support transport. These kinds of taxes are implemented in Denver, New Orleans, Atlanta, Reno, Fort Worth, Austin and San Francisco [15]. Outside the United States, this system of obtaining funds to finance public transport is found in India.

Apart from consumption taxes in the United States, there are also gambling taxes used for financing public passenger transport. The part of revenues from lotteries is assigned for public transport. However, in general, lotteries are perceived as a controversial source of revenue. Critics point at the negatives of gambling - there is a chance for corruption and a high participation rate of poor people. This kind of tax system exists in Maricopa County (Arizona) and in Pennsylvania [8].

\subsection{Cross-utility financing}

Cross-utility financing does not necessarily have to be an unconventional mechanism regarding its extensive application 
in the parts of Europe, North America and elsewhere. There are two types of cross-utility financing in practice. The first is the fee (tax) for the use of a (public) service similar to the sales tax and employer tax. In the other type, a public transport department that makes a loss is cross-financed by a profitable department of public services. The revenue depends on outside factors, such as economic conditions and social trends.

The first type was found in Pullman, Washington. The transport in Pullman is paid for by a $2 \%$ charge on telephone, water and sewage (the city is the owner), electricity, gas and the fee for the rubbish. The companies which offer these services collect the tax. Then, the tax is forwarded to Pullman and then to the transport department. The taxes cover $40 \%$ of operational costs of fourteen town's vehicles, road services and para-transit services. Other examples are found in Springfield, Missouri and New Orleans where the fee from the electricity sales is used to finance public transport.

There is cross-financing system in Europe as well. In Germany (e. g. Wuppertal), systems of public transport are local departments and as such they are often subsidised from revenues of other town's departments like water, gas and electricity that make excess profit. This fact allows the town to compensate for the losses in transport with any revenues, which means that these revenues are not subject to corporation tax. Similar conditions have been adopted in some Italian (Milan) and Austrian cities and in Luxembourg.

\section{Conclusion}

Nowadays, contracting authorities use financial resources from their own budgets which are necessary for the compensation of provable financial loss which arises from the operation of transport services. The amount of their budgets is limited and there are no specific sources dedicated to the financing of public passenger transport.

It is not possible to create a bigger source of financing by increasing the fares. According to the price elasticity of demand, the increasing of the fare would motivate passengers to change their means of transport. Nowadays, the Slovak Republic plans to build integrated transport systems which would attract passengers to travel by public passenger transport, and which would represent a tool for increasing the road safety. However, the building of integrated transport systems requires a higher financial support from public sources. That is the reason why it is important to identify new ways of obtaining resources from other sources.

\section{Acknowledgement}

This paper was supported by "Agentura na podporu vyskumu a vyvoja" based on the Contract No. SK-PL-20150019.

\section{References}

[1] PARRY, I. W. H., SMALL, K. A.: Should Urban Transit Subsidies Be Reduced? American Economic Review, vol. 99, No. 3, 2009, 700-724.

[2] BLY, P. H., WEBSTER, F. V., POUNDS, S.: Effects of Subsidies on Urban Public Tran-Sport. Transportation, vol. 9, No. 4, 1980, 311-331.

[3] BUEHLER, R., PUCHER, J.: Sustainable Transport in Freiburg: Lessons from Germany's Environmental Capital. Intern. J. of Sustainable Transportation, vol. 5, No. 1, 2011a, 4370.

[4] PUCHER, J., MARKSTEDT, A.: Consequences of Public Ownership and Subsidies for Mass Transit: Evidence from Case Studies and Regression Analysis. Transportation, vol. 11, No. 4, 323-345.

[5] VARJAN, P.: The Proposal of the Methodology of the Funding Sources in Public Passenger Transport, dissertation thesis, adviser: doc. Milos Poliak, Zilinska univerzita.

[6] POLIAK, M.: The Relationship between the Fair Profit and Risk in the Public Passenger Transport in the Slovak Republic, Ekonomicky casopis/J. of Economics, vol. 61, No. 2, 2013, 206-220.

[7] FARRELL, S.: Financing European Transport Infrastructure: Policies and Practice in Western Europe, London: Macmillan. ISBN 033-37-189-68.

[8] UBBELS, B., NIJKAMP, P.: Unconventional Funding of Urban Public Transport. Transportation Research, Part D, 7, No. 1, 317-329, 2002.

[9] NEDELIAKOVA, E., SEKULOVA, J., NEDELIAK, I., ABRAMOVIC, B.: Application of Raymond Fisk Model in Research of Service Quality, Communications - Scientific Letters of the University of Zilina, No. 2, 2016, 11-14.

[10] BUSHELL, C.: Jane’s Urban Transport Systems 1993=94, Jane’s Information Group, Coulsdon: Surrey, 1994.

[11] SIMPSON, B. J.: Urban Public Transport Today, E\&FN Spon: London, 1994. 


\section{COMMNICOIIONS}

[12] SIMS, L., BERRY, J.: Various Ways of Recovering Increases in Land and Property Values - The Example of North America, UITP seminar, Paris, October 1999.

[13] KALASOVA, A., CERNICKY, L., KUBIKOVA, S.: Microscopic Simulation of Coordinated Route in the City of Zilina, Communications - Scientific Letters of the University of Zilina, No. 2, 2014, 46-50.

[14] LIZBETIN, J., KAMPF, R., STOPKA, O., BARTUSKA, L., CEJKA, J.: The Current Status of Intermodal Transport Terminals in the Slovak Republic, Horizonts of Railway Transport 2015: Anniversary, vol. 1, 2015, 143-147, University of Zilina, ISBN 978-80-554-1097-5.

[15] BLACK, A.: Urban Mass Transportation Planning. McGraw-Hill : New York, 1995. 